\title{
A Field Study: An Examination Of Managers' Situational Leadership Styles
}

Tom Henkel, Embry-Riddle Aeronautical University, USA

Debra Bourdeau, Embry-Riddle Aeronautical University, USA

\begin{abstract}
The present study explored the applicable situational leadership styles of experienced military managers attending an advanced leadership educational program. While attending this program, these managers were requested to reveal the results of their situational leadership self-assessment in which they participated. A total of 620 managers agreed to reveal their results, and descriptive statistics were conducted to determine the findings of their situational leadership self-assessments. The study research results revealed two situational leadership styles were predominating: (Telling and Participating). The findings of research study have significant implications for managers when leading individuals and teams for organizational success. These findings also may contribute to better understanding of the situational leadership styles which characterize managers when leading people and team members. Additionally, the findings of this study also have implications for teaching situational leadership skills in a variety of settings to include educational leadership programs such as the one reported here.
\end{abstract}

Keywords: Managers; Situational Leadership; Maturity Readiness

\section{INTRODUCTION}

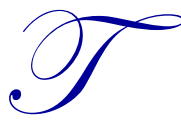

he question of whether leaders are born or made has been central to even the earliest studies on the topic. Specifically, researchers have sought to determine whether certain personal attributes such as intelligence, honesty, self-confidence, appearance, or energy occur more frequently in leaders or make one more apt for leadership roles (Daft, 2014). This research resulted in several approaches and theories of leadership to include the Trait Leadership Theory which was an attempt to determine whether there was a universal set of leadership effectiveness characteristics such as physical size, wealth, age, intelligence and education, among others (Lussier \& Achua, 2016). After years of research, a few traits emerged as ostensibly important; however, the Trait Leadership Theory failed to produce a definitive list of key leadership traits or one type leadership style to be used in all situations needed for organization success (Yukl, 2011; Daft, 2014; Lussier \& Achua, 2016).

\section{The Ohio State Studies}

After the leadership trait approach did not produce one best set of leadership attributes, researchers started to look at a number of alternative ideas and finally settled on pursuing leadership styles as a relationship between a leader's behavior and subordinates' satisfaction and performance. The result provided a stepping stone for the beginning of the leadership behavioral leadership phase which lasted from the late 1940s to the early 1960s. One of the well-known research efforts was the Ohio State University Leadership studies which were based on examining how the leader behaved when he or she was in charge of a team or organization's employees (Stogill \& Coons, 1957). Based on this research, two wide-ranging classifications of leader behavior types emerged: consideration (the degree to which a leader exhibits concern for subordinates by acknowledging their ideas and feelings, enthusiastically works to ensure mutual trust, seeks their input, actively listens, consults with them on important matters or problem solving, expresses a clear willingness to accept suggestions, and treats them as equals) and initiating structure (the degree to which a leader exhibits task orientation by defining the subordinates' roles and duties, directing their work activities toward goal achievement, ruling with an "iron hand," criticizing poor work, emphasizing the importance of meeting deadlines, and offering new approaches to problems) (Daft, 2014). According to the Ohio State Leadership Studies, a leader can display a high degree of both consideration and initiating structure, a low degree of both types, high consideration and low initiating structure, or low consideration and high initiating structure behavior (Stogill \& Coons, 1957). Research indicates that all four types of leader style combinations can be effective (Daft, 2014). 


\section{The Michigan State Studies}

The Michigan State studies reported three types of behavior that can determine whether a leader will be effective or ineffective (Yukl, 2011). These three types of leadership behavior included task-oriented behavior, relationshiporiented behavior, and participative behavior. The task-oriented leader spent more time on work and less time on subordinates' needs. This is similar to the behavior labeled as initiating structure in the Ohio State studies (Stogill \& Coons, 1957). Relationship-orientated leaders showed more support and care for subordinates. This is similar to what the Ohio State studies called consideration behavior (Stogill \& Coons, 1957). The third behavior identified by the Michigan State studies was participative leadership which is characterized by group regulation rather than individual supervision of each subordinate (Daft, 2014).

In summary, The Ohio State and University of Michigan studies differ in that the University of Michigan studies position leadership behaviors on a continuum while the Ohio State model considers the behaviors independent of one another, offering four possible distinct behavior styles (Lussier \& Achua, 2016). Just as the Trait Leadership Theory attempted to find a definitive list of the preeminent attributes for all successful leaders, behavior-focused leadership theories were also an attempt to find one leadership style that was the ideal to use in all situations. However, neither one produced that specific leadership style that was appropriate in every scenario (Yukl, 2011; Daft, 2014; Lussier \& Achua, 2016). This led to the rise of the contingency theories of leadership which take as their premise the idea that style is dictated by situation (Yukl, 2011).

\section{Fiedler's Leadership Contingency Theory}

Early contingency theories included Fred E. Fielder's determination that leaders were either task-oriented or relationship-oriented. Fielder's 1967 study further defined task-oriented leaders as ones who are concerned with details and who are reluctant to develop action plans without clear and convincing evidence. Relationship-oriented leaders, in contrast, are results driven and need few facts before developing action plans (Fiedler, 1967; Daft, 2014). Fiedler (1967) proposed that using the best style of leadership is not a matter of finding any one best style but the most effective style for a particular situation (Ionesu \& Negrusa, 2007). Fiedler also proposed that a leader's effectiveness depended on three major situational variables that determine whether a given situation is favorable to leaders: (a) leader-member relations in which employees trust, accept, respect, and have confidence in their leader; (b) the degree of structure of the assigned task being performed; and (c) whether the leader's position of power is strong or weak (Kest, 2006). Fiedler suggested that task-oriented leaders are most effective in work environments where they have either a great deal of control or very little control. Conversely, relationship-oriented leaders are most effective when the situational control is moderate.

Fiedler's contingency theory has been criticized by some researchers; however, empirical research has supported many of the specific propositions of the theory. Regardless, Fiedler's contingency theory remains an important contribution to the understanding of leadership effectiveness, although interest has turned to newer and better situational leadership theories (Yukl, 2010). The Situational Leadership theory by Hersey and Blanchard (1982) addressed some shortfalls of Fiedler's contingency theory (Gilstrap, 2009).

\section{The Path-Goal Theory of Leadership}

Another contingency approach to evolve was the path-goal theory of leadership. This theory focuses on how the leader's behavior motivates the followers by influencing their views of what may occur based on their different levels of efforts on the job. In other words, the path-goal theory of leadership describes the way leaders encourage and support their followers to achieve the organization's goals and objectives; this is done by clearing a path that allows the followers to determine which way to go, removing the roadblocks, and providing rewards for performance (House \& Mitchell, 1974).

Using the Path-Goal Contingency Leadership theory, the leader may be supportive, directive, participating, or achievement-oriented (Yukl, 2011). The leader's style depends on the situation, including the follower's capability and motivation, as well as the difficulty of the job and other contingency related factors. In removing hindrances encountered along the path, the leader may take the action or assist the follower in eliminating the obstacle. Leaders also may present the followers with a variety of rewards based on the available resources; common rewards include public recognition or even financial incentives (Daft, 2014). 
In summary, the Path-Goal Leadership theory links leadership behavior with the contingency variables by selecting the appropriate behavior style, and the leader assists the followers to achieve their goals and objectives of the organization (House \& Mitchell, 1974). Although the Path-Goal Contingency Leadership theory has limitations, it provided a baseline for future leadership researchers to refine the situational variables related to leadership when leading (Yukl, 2011).

\section{Situational Leadership Theory}

A contingency leadership theory which has seen a rise in popularity over the years was originally developed by Hersey and Blanchard and is known as the Situational Leadership Theory (Hersey \& Blanchard, 1982). The theory provides an avenue for managers to learn and develop different types of leadership styles and choose the most appropriate one based on an employee's or a team's maturity/readiness to perform the specific task or project under contemplation (Hersey, Blanchard, \& Johnson, 2013). The Situational Leadership Theory is based on two behavioral categories: task behavior and relationship behavior as first described by Fred Fielder (1967). Managers that are task-oriented have a tendency to focus on details and want all the details associated with the task before taking action. Conversely, managers who are relationship-oriented try to create trust and respect with the employees/team members allowing them to be part of developing an action-plan (Daft, 2014). This continuum is represented in Figure 1.

Figure 1. The Leadership Continuum. Source: (Arora \& Baronikian, 2013).

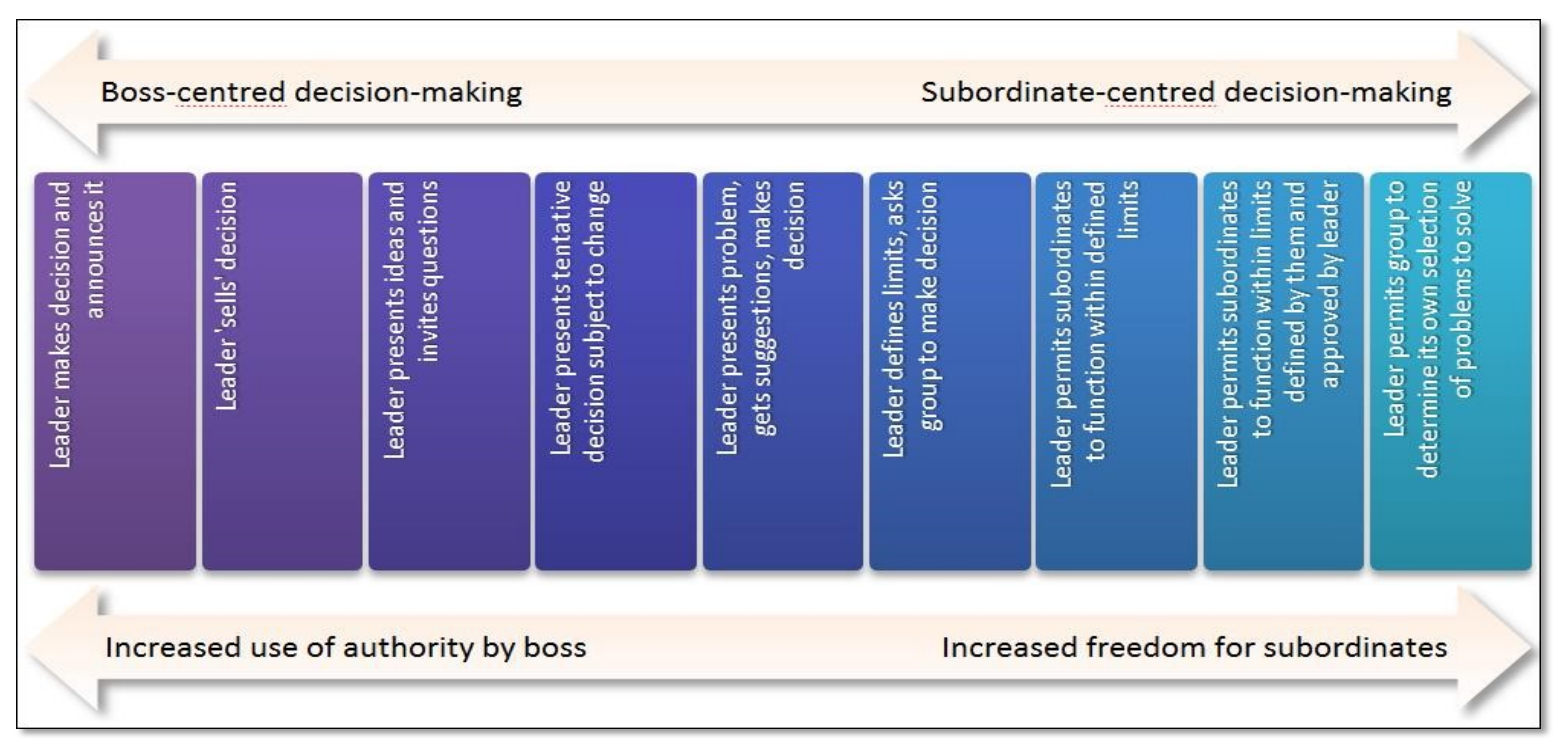

\section{Employees' and/or Team's Maturity/Readiness}

The Situational Leadership Theory provides a balance between task behavior and relationship behavior based on the employees' or team's maturity (readiness) level for a specific task or project deliverables (Hersey, Blanchard, \& Johnson, 2013). Maturity/readiness is a combination of competence (task-relevant knowledge and skills, as well as transferable skills). Commitment (to include motivation, self-conference, and attitude toward others) is generally associated with a project manger's interpersonal skills. The situational leadership theory outlines four levels of maturity/readiness to include: with the low level of maturity/readiness employees may be new to the job, may lack the necessary job knowledge, skills, confidence or motivation to complete the task by themselves and/or a team may be in the forming stage of team building. Employees, or a team at the moderate level of maturity/readiness, may be willing to complete the assigned task, but they may lack some education and experience for the job or project to complete the work successfully. Employees or a team at the high moderate level of maturity/readiness level may have the knowledge, education, and demonstrated skills to perform the work or project, but they may not have confidence in their abilities or the goal of the assigned work/mission. Employees or teams at the high maturity/readiness level are able to work on their own. They have high confidence, commitment, needed strong skills, and they take ownership of the task (Hersey, Blanchard, \& Johnson, 2013). When using the situational leadership theory developed by Hersey \& Blanchard (1982), the most 
appropriate leadership style for the manager to use is the one that is well matched to the maturity/readiness level of the employees or team members in a given situation (Arora \& Baronikian, 2013).

\section{Four Situational Leadership Styles}

The theory of situational leadership theory is based on four leadership style choices instead of one single fixed leadership approach being the best style approach for every situation. The different types of situational leadership styles for a given situation based on an employee's or team's maturity include:

Telling: High Task/Low Relationship

Selling: High Task/High Relationship

Participating: Low Task/High Relationship

Delegating: Low Task/Low Relationship

Figure 2. The Situational Leadership Model. Source: (Arora \& Baronikian, 2013).

\begin{tabular}{|c|c|c|c|}
\hline $\begin{array}{l}\text { Moderate } \\
\text { Maturity } \\
\text { Before making } \\
\text { a decision, I } \\
\text { want your } \\
\text { input... }\end{array}$ & $\begin{array}{l}\text { Participating } \\
\text { Appreciative, } \\
\text { Considerate }\end{array}$ & $\begin{array}{l}\text { Selling } \\
\text { Adaptive, } \\
\text { Coaching, }\end{array}$ & $\begin{array}{l}\text { Moderate } \\
\text { Maturity } \\
\text { Based on my } \\
\text { decision, here } \\
\text { is what I want } \\
\text { you to do, } \\
\text { because... }\end{array}$ \\
\hline $\begin{array}{r}\text { Low } \\
\text { Task-Oriented } \\
\text { Behavior } \\
\text { [Less Directive] }\end{array}$ & $\begin{array}{l}\text { Patient, } \\
\text { Supportive, } \\
\text { Understanding }\end{array}$ & $\begin{array}{l}\text { Interactive, } \\
\text { Involving, } \\
\text { Resourceful }\end{array}$ & $\begin{array}{l}\text { High } \\
\text { Task-Oriented } \\
\text { Behavior } \\
\text { [More Directive] }\end{array}$ \\
\hline $\begin{array}{l}\text { High } \\
\text { Maturity } \\
\text { You make the } \\
\text { decision... }\end{array}$ & $\begin{array}{l}\text { Analytical, } \\
\text { Deliberate, } \\
\text { Methodical, } \\
\text { Organized, } \\
\text { Reflective }\end{array}$ & $\begin{array}{l}\text { Decisive, } \\
\text { Directing, } \\
\text { Determined, } \\
\text { Forceful, } \\
\text { Stucturing }\end{array}$ & $\begin{array}{l}\text { Low } \\
\text { Maturity } \\
\text { Based on my } \\
\text { decision, this } \\
\text { is what I want } \\
\text { you to do... }\end{array}$ \\
\hline
\end{tabular}

Hersey \& Blanchard (1982) contend that not all employees/teams are created identical; therefore, a manager, before applying a leadership style, should analyze the maturity/readiness of the employees or the team which includes being knowledgeable, willing, and eager to complete the task or project work. Once the manager has analyzed the employees' or team's maturity/readiness, then the manager can apply the leadership style that is appropriate for the situation. When reviewing Figure 2, we see that low maturity/readiness usually is associated with new employees and/or teams which have low confidence, limited knowledge or skills necessary to work independently on a tasking or a project. This situation calls for a manager to be very specific, providing a clear direction of what is needed to accomplish the task or project by answering the "who, when, what, when, and how" aspects of the task assignment or project work. Thus, the manager needs to employ a "Telling" leadership style. Employees/teams at the moderate 
maturity/readiness level generally have the will to complete a task or project, but lack the capacity to do so independently; therefore, some direction is given. However, the manager seeks input from the employees/team to clarify the tasks or project rather than merely instructing on how task or project is to be accomplished. In this case, the manager uses a "Selling" leadership style to boost the employees'/team's buy-in of the goals and objectives of the assigned work or project. A high moderate maturity/readiness level calls for a manager to use a "Participating" leadership style because the employees/team have the performing skills necessary for completing the task or project but may be insecure at times when it comes to accomplishing the organization's goals and objectives. For example, the employees/team may ask, "Why are we even doing this tasking or project?" Therefore, this leadership style is used to boost employees' or a team's willingness and sense of security when there is already the ability to successfully compete the assigned work or project. When employees/teams are at a high maturity/readiness level, now the manager can apply a "Delegating" leadership style to empower the employees or team to work independently, and the manager only offers assistance when needed (Hersey \& Blanchard, 1982; Daft, 2014; Arora \& Baronikian, 2013). In sum, although there is no one specific leadership style to use on all occasions, the Situational Leadership Theory states that the successful manager will adapt his or her leadership style to match the maturity/readiness level of the employees or team based on the circumstances or life cycle stage of the project (Hersey, Blanchard, \& Johnson, 2013; Arora \& Baronikian, 2013).

\section{PURPOSE OF THE STUDY}

The purpose of this research study was to explore the situational leadership behavior styles used by military managers who attended a U.S. military advanced management leadership program. These managers had experience ranging from being a first line supervisor to that of experienced middle managers who managed first line supervisors. Both types of managers had experience leading employees and teams to accomplish the organization's mission and goals.

\section{METHODOLOGY}

Thus, we began our consideration of managers' preferred situational leadership styles with the following research question:

Which situational leadership styles are reported by military managers when leading followers and/or teams?

To find the answer to this research question, a comprehensive literature review was completed followed by a descriptive statistics analysis, and the managers' reported self-assessment results.

\section{DATA COLLECTION}

As a requirement of attending U.S. military advanced leadership academic program, managers responded to a situational leadership self-assessment. Once completed, the managers were asked to volunteer the results of their selfassessment to include their preferred situational leadership style and secondary preferred leadership style(s). These managers worked in various work environments to include the active duty, reserves, and National Guard across the United States and internationally. In total, 620 managers volunteered to report their situational leadership selfassessment results. Respondents' privacy and confidentiality were strictly protected.

\section{DISCUSSION}

Studies have revealed that most managers have a primary leadership style and a secondary leadership style when leading employees or team. A manager will use a primary leadership style that is used most often when attempting to influence and leading employees and teams. In other words, most managers, tend to have a favorite or "default" leadership style when leading employees or teams (Hersey \& Blanchard, 1974) and a secondary or supporting style(s) leadership style when he or she will use when the particular occasion occurs. It is important to note that all managers have a primary leadership style; that is, they tend to use one of the four basic leadership styles. However, they may not have any secondary leadership style or have up to three secondary leadership styles (Hersey, Blanchard, \& Johnson, 2013).

No matter if the manager uses a primary or secondary situational leadership style, Paul Hersey (2009) suggested that the manager ought to ensure he or she communicates clearly to ensure the employee or team members understand the 
goals and objectives to successfully complete the tasking or project deliverables. Once this has been successfully communicated and fully understood by all to include addressing any misunderstandings, then the manager can diagnose the maturity/readiness level of the employee or team that he or she is trying to influence for the successful completion of the tasking or project.

Of the 620 military managers volunteering the results of their situation leadership self- assessment, two leadership styles were predominant: Selling and Participating. Notably, 398 managers (64.19\%) reported a Selling situational leadership style. Additionally, 203 of the 620 managers (32.74\%) reported a Participating leadership style. Moreover, 159 of the 398 managers that reported a Participating leadership style, also reported a secondary Selling leadership style. These managers tend to do well working with employees/teams of average levels of readiness/maturity but may find it difficult handling discipline problems with immature work groups, as well as delegating to high maturity/readiness employees/teams to maximize their productivity. This combination of situational leadership styles tends to be the most frequently identified leadership style in the United States and other countries with a high level of education and extensive industrial experience. Managers in some of the emerging cultures tend to have a more structured style profile (Hersey \& Blanchard, 1982).

Furthermore, 131 of the 203 managers who reported a Participating primary situational leadership style also reported a Selling secondary leadership style. These managers may participate in the decision-making process, but delegate important tasks to employees. These managers, when leading, may create the roles and objectives for others, but they are also open to suggestions and opinions. They "sell" their ideas to others in order to gain cooperation (Hersey \& Blanchard, 1982). Additionally, 72 of the 620 managers reported a primary leadership styles of Selling with both the secondary leadership styles of the first two groups of senior managers. These managers tend to be effective working with all types of people except those very mature/highly ready and competent people who need delegation in order to maximize their performance (Hersey \& Blanchard, 1982).

Research has revealed that it is appropriate for first-line supervisors to have a basic situational leadership style of Selling, and a supporting leadership style of Telling. However, when these first-line supervisors are promoted to middle management, it is more suitable if they use a primary Selling leadership style and a secondary Participating leadership style (Hersey \& Blanchard, 1982).

\section{SUMMARY}

Nazar (2013) noted, "Statistics show that in the U.S. approximately 543,000 new businesses get started each month, but more businesses shut down than start up each month p.1." In many cases, the business closures can be attributed to ineffective leadership (Myatt, 2012). Hersey and Blanchard (1982), developers of the Situational Leadership Theory, state that the successful business has a major attribute that sets it apart from unsuccessful businesses - dynamic and effective leadership.

This present research study was designed as an exploratory measure by surveying managers attending a military advanced leadership program which served as a useful framework to identify their situational leadership styles used for data collection. A total of 620 managers responded to the survey. The results show that these managers report a primary leadership style and a secondary leadership style. Additionally, this study has the intent of contributing to a better understanding and improvement of situational leadership behavior skills of these managers. Ideally, the results of this current research will assist managers in adopting the most appropriate leadership style necessary for success when leading employees and or teams. Moreover, the findings of this study also have implications for the teaching of situational leadership theory concepts in a variety of educational and training settings.

In conclusion, effective management principles such as planning, coordinating, and controlling are necessary for organizational success; however, leadership skills are especially important for success of the organizational goals and objectives. To be an effective manager, it is important to note that there is no single solution to lead employees/teams. To this end, the situational leadership theory provides a practical approach and thus assists managers in understanding and applying a leadership style(s), which includes telling, selling, participating, or delegating, to be used when dealing with employees/teams. Hopefully, this research study shows why a situational leadership self-assessment is an important tool to assist managers in reflecting on the many skills and attributes of leadership, both the ones the manager already possesses and the one he or she would like to develop (Arora \& Baronikian, 2013). The findings of this research study also have implications for teaching leadership situational leadership skills in a variety of settings. 


\section{AUTHOR BIOGRAPHIES}

Tom Henkel is an Associate Professor in the Department of Leadership and Management at Embry-Riddle Aeronautical University. His research interests include leadership, management, and project management. He earned a doctorate in Adult Leadership from Auburn University, and a doctorate degree in Business Administration from Northcentral University. Thomas.henkel@erau.edu

Debra Bourdeau is an Assistant Professor in the College of Arts and Sciences at Embry-Riddle Aeronautical University. She earned a Ph.D. in English from the University of Georgia. Her research interests include interdisciplinary humanities, specifically the exploration of STEM fields through the lens of humanities disciplines. taylo13f@erau.edu

\section{REFERENCES}

Arora, M. \& Baronikian, H. (2013). Leadership in project management: Leading people and projects to success ( $7^{\text {th }}$ ed.). Toronto, Canada: Leadership Publishing House.

Daft, R. (2014). The leadership experience (6 $6^{\text {th }} \mathrm{ed}$.). Canada: Thomson/South-Western.

Fiedler, F. (1967). A theory of leadership effectiveness. New York: McGraw-Hill

Gilstrap, D. L. (2009). A complex systems framework for research on leadership and organisational dynamics in academic libraries. Libraries \& the Academy, 9(1), 57-77.

Hersey, P. \& Blanchard, K. (1982). Management of organizational behavior. Englewood Cliffs, New Jersey: Prentice Hall, Inc.

Hersey, P. \& Blanchard, K. (1974, February). So you want to know your leadership style? Training and Development Journal, $1-15$.

Hersey, P., Blanchard, K., \& Johnson, D. (2013). Management of organizational behavior - Leading human resources. Pearson Prentice Hall: Upper Saddle River, NJ:

Hersey, P. (2009). Situational leaders. Leadership Excellence, 2(6), 2.

House, R. J., \& Mitchell, T. (1974). Path-goal theory of leadership. Journal of Contemporary Business, 3, 1-97.

Ionesu, G. \& Negrusa, A. (2007). Leadership, motivation, and Excellence (a comparative view). Theoretical and Applied Economics, 2(507), 33-40.

Kest, R. (2006). Principles of leadership: Leadership management. Futurics, 30(1/2), 52-71.

Lussier, R. \& Achua, C. (2016). Leadership: Theory, application, \& skill development. (6 ${ }^{\text {th }}$ ed.). South-Western: Mason, OH.

Nazar, J. (2013, September 9). 16 surprising statistics about small businesses. Forbes. Retrieved from https://www.forbes.com/sites/jasonnazar/2013/09/09/16-surprising-statistics-about-small-businesses/\#587701da5ec8.

Myatt, M. (2012, January 12). Businesses don't fail - leaders do. Forbes. Retrieved from https://www.forbes.com/sites/mikemyatt/2012/01/12/businesses-dont-fail-leaders-do/\#70b1b0706c97iv

Stogill, R, \& Coons, A. (1957) Leadership behavior: Its description and measurement. Columbus: Ohio State University, Bureau of Business Research.

Yukl, G. (2011). Leadership in organization (7 $7^{\text {th }}$ ed.). Prentice Hall: Upper Saddle River, NJ. 
NOTES 